\title{
胆石の成因
}

\section{Pathogenesis of Gallstones}

\author{
鈴 木 範 美*，伊 勢 秀 雄** 新 谷 史 明** \\ Noriyoshi SUZUKI Hideo ISE, \\ 高 橋 良 延, * 田 中 純 一** \\ Fumiaki SHINYA \\ Yoshinobu TAKAHASHI and Junichi TANAKA
}

Key Words : Gallstone, Cholesterol, Bilirubin, Coagulation, Agglomerate

はじめに

胆石は，胆汁を母体として生成するてとには異論は ないが, 胆道系で生成される胆石の種類は種々様々で ある。一体何が原因で胆石が生成し，いかなる条件で 種々の胆石が形成されるのであろうか。胆石に関する 研究は枚挙にいとまがないが，その成因は未だ明らか ではない。わが国の胆石症は，近年コレステロールを 主成分とする胆石が著しく増加し，ビリルビン色素を 主成分とするビリルビンカルシウム石は激減している。 また，胆石の外観と割面が黒色を呈する黒色胆石の増 加も興味のあるとてろである。日本人の胆石保有率は $10 \%$ 前後といわれているが, その頻度からみて良性 疾患ではあるが注目すべき疾患の一つである。

今回は胆石を代表するコレステロール胆石とビリル ビンカルシウム石の成因について教室の成績を織り込 みながら述べるととにする。

\section{1. 胆汁の組成}

胆汁は，肝で生成されて胆衰で濃縮・眝蔵され，食 物が胃から十二指腸に到達すると，主に消化管ホルモ ンの作用で胆囊が収縮して胆汁は総胆管を経て十二指

\footnotetext{
昭和 62 年 10 月 7 日受付

* 東北大学医療技術短期大学部 (T980 仙台市星陵町 2-1)

TEL 022-274-1111 内線 3625

** 東北大学医学部第一外科学教室 (千980 仙台市星陵町 1-1)

TEL 022-274-1111内線 2552

〈著者紹介〉
}

鈴木範美 :

昭和 41 年東北大学大学院医学研究科修了

昭和 54 年東北大学医療技術短期大学部教授兼東北大学医学部第一 外科講師 現在に至る。

胆石の成因ならびに胆道生理に関する研究
腸に送り出される(図 1 )。そして胆汁は, 食餌中の脂 肪の消化吸収を助ける生理的意義と体内に生じた老廃 代謝産物を肝で解毒して胆汁中に放出して体外に排泄 する役目を有している。胆汁は有機，無機物質を含む コロイド溶液で固形成分は数\%以下である。固形成分 の大部分は有機化合物で, 胆汁酸, リン脂質 (90\%以 上はレシチン), コレステロール，胆汁色素，蛋白質， ムチンなどである。肝でコレステロールから生成され た一次胆汁酸は腸内細菌の㗢きにより,さらに二次胆 汁酸となる。乙れらの胆汁酸は小腸の末端から吸収さ れて肝に戻り再び胆汁中に排泄される。すなわち，胆 汁中の胆汁酸は腸肝循環を行なっている。コレステロ ールは，主に肝で生成される。胆汁中のコレステロー ルはそのほとんどが水不溶性の遊離型であり, 胆汁中 に存在するためには特殊な溶存機構が必要となる。そ れについては後述する。

一方, 胆汁色素は赤血球の崩壊産物の Heme由来の Tetrapyrrole 核を有する種々の誘導体からなる物質で,

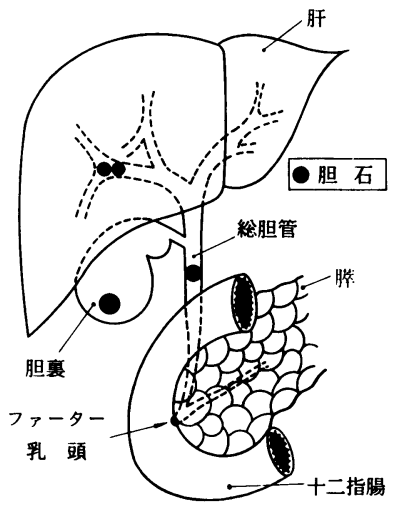

图 1 胆道系之胆石 
表 1 胆汁組成と胆石の種類

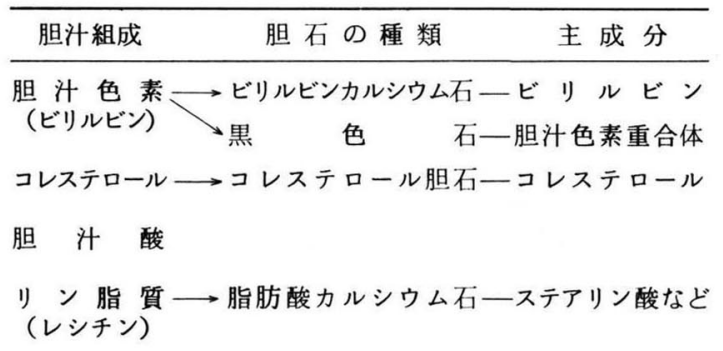

無機物質 $\longrightarrow$ 炭酸カルシウム石一炭酸カルシウム

主体はビリルビンである。ビリルビンは大部分が抱合 型として水溶性となり胆汁中に排泄される。胆汁の黄 褐色色調は，乙の色素に由来するものである。肝から 分泌されたこれらの諸物質を含む胆汁 (肝胆汁)は, 一 部胆囊内に貯蔵されて約 $5 \sim 10$ 倍に濃縮される。

胆汁から生成する胆石は, その外観, 割面構造, 組 成, 大きさ, 数などまったく種々様々である(表 1)。 基本的には胆汁中のコレステロールを主成分とする胆 石と，ビリルビンを主成分とする胆石とに大別 ${ }^{1)}$ でき る。

\section{2. 胆石の成因}

胆石の成因は, 胆石の種類別にその誘因, 主成分の 析出機構, 結石化機構の三つに分けて論ずる必要があ る。

\section{1 コレステロール胆石}

コレステロールを主成分とする胆石で主に胆囊で生 成される(図 1)。このコレステロール胆石(以下コ石) は, 通常純コレステロール石, 混成石, 混合石の三つ のタイプに分けられる。

純コレステロール石 (図 2) は, 構成成分のほとんど がコレステロールで割面では中心部からコレステロー ルの結晶が放射状に配列している。われわれは中心部 の色素塊を通常「核」と呼称している。混成石は, 純

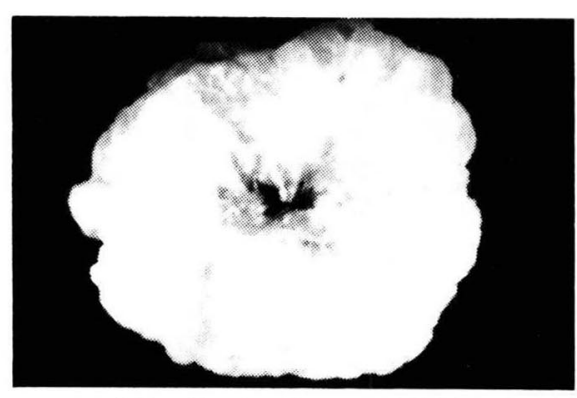

図2 純コレステロール石(割面)
コレステロール石の外側に他の成分が析出して割面で 内層と外層に区別できる胆石であり, 混合石はコレス テロールを主成分とするものの, 色素成分が $5 \%$ 前後 含有されるために茶褐色を呈し, 割面で放射状構造が 認められる胆石である。乙れらの胆石の化学分析では $90 \%$ 以上がコレステロールである。

\subsection{1 誘 因}

古くから食生活との関係が注目されていた。事実西 欧では最も頻度の高い胆石であるが, わが国では戦後 食生活の西欧化(高脂肪・高蛋白食) 亿伴い, 胆石症の 増加ととむに激增した。このことは食生活とコ石の生 成が密接な関係にあるととを物語っているあのである。 食生活の中であ高コレステロール食, 高カロリー食, 摄取する脂肪の種類 (動物性脂肪, 飽和脂肪酸)などが 胆石の生成に関係するようである。肥満者に胆石症が 多いととは衆知の通りである。次に女性に多いてとで あるが, 妊娠之胆石症の関係は明白ではないが, 女性 ホルモン剂の服用は胆汁を胆石生成促進性(催石性) と するし, 経口的避妊剤投与では胆石生成の増加が認め られている。また薬剤クロフィブレートの長期服用は 血中コレステロールの胆汁中排泄を促進し, 回腸疾患 による胆汁酸の吸収障害, 糖尿病なども胆石誘発疾患 として問題となっている。

一方, 遺伝・人種差などもコ石生成の誘因として指 摘されている。

\subsection{2 コレステロールの析出機構}

(1) コレステロールの溶存

コレステロールは, 胆汁中では胆汁酸とレシチンが 形成する複合ミセル(Mixed micelle)に取り込まれて 存在している。胆汁酸は, 親水基と疎水性部分を有 する両親媒性物質の界面活性剂で, これはCritical Micelle Concentration (CMC) 以上では複数個の分 子が会合してミセル(Micelle)を形成し，てのミセル の中央部にコレステロールなどの脂溶性物質を取り込ん で溶存 ${ }^{2)}$ することができる。また，レシチンむ界面活 性剂であり,それ自体は水に難溶である(図 3)。胆汁 中ではこの胆汁酸とレシチンの両界面活性剂で形成す る複合ミセルがコレステロールを溶存するわけである。 Admirand と Small ら³は人胆汁を用いたモデル 実験から,コレステロールのミセル溶存は, その絶対 濃度で規定されずコレステロール, 胆汁酸, レシチン の三者の相対濃度(相対モル\%)によることを明らかに して, 三角図(Triangular phase diagram) を作製 した(図 4 )。そして三角図では, コレステロールが溶 存可能な領域をミセル層 (Micellar zone)とし，それ 


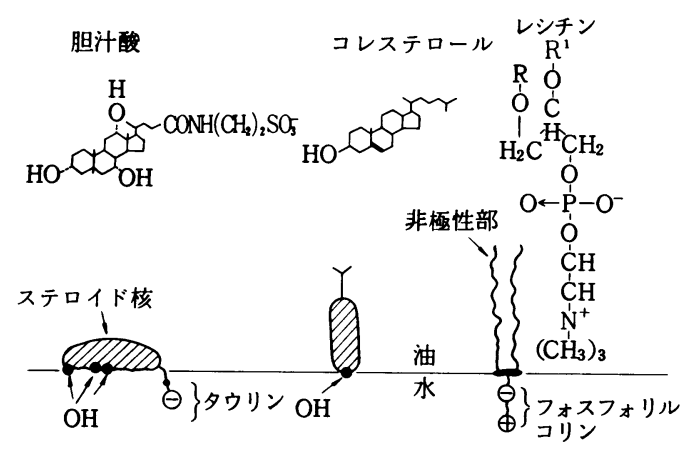

図 3 胆汁中脂質の分子模型

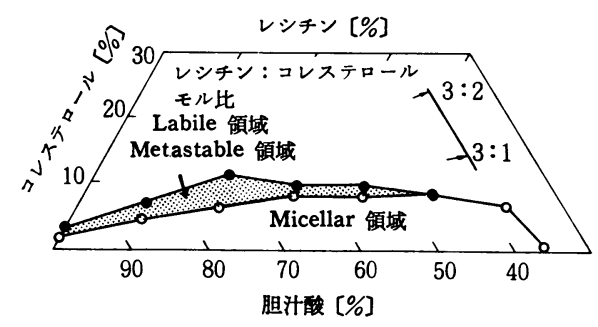

图 4 コレステロール析出機構

を逸脱すればコレステロールが過飽和となり，コレス テロールが析出結晶化するとした。このコレステロー ル過飽和胆汁は一般に催石性胆汁 (Lithogenic bile) といわれている。その後, Holzbach ら4) はての三角 図上のコレステロール溶存の臨界線を修正し、Admirand-Small 線との中間の領域を Metastable supersaturated zone と称し，コレステロールは過飽和で はあるがその程度が低く結晶の析出機構が異なること を示した。

（2）催石性胆汁 (Lithogenic bile）の生成機構

一般にコ石症例の肝から分泌される胆汁は，すでに 催石性胆汁の状態であることが証明されている。さて, ての催石性胆汁の産生機構であるが, 胆汁酸, レシチ ン, コレステロールの三者の関連性から考えると,コ レステロール過飽和胆汁の生成は胆汁中へのコレステ ロールの排泄増加，または胆汁酸とレシチンの排泄減 少の組み合わせによるあのといえる。

コ石症例における肝生検の検討では, コレステロー ルの生合成の律速酵素 HMG - CoA reductase活性の 上昇とコレステロールから胆汁酸への生成を律速する 酸素 Cholesterol $7 \alpha$-hydroxylase 活性の低下が みられたことから, 肝におけるコレステロール合成立 進之胆汁酸生成の減少により催石性胆汁が生成される あのと考えられている。また, 胆汁酸の腸管からの吸 収障害で胆汁酸の腸肝循環の損失が大量に起こると,
肝での胆汁酸合成が代償できず胆汁酸プール量が減少し て結果的に催石性胆汁となることも判明している。また, リン脂質の胆汁中排泄は胆汁酸依存性であるが、コレ ステロールの排泄はリン脂質ほど胆汁酸依存性はない。 したがって，胆汁酸の排泄量が低下するとリン脂質む それに伴って減少するが, コレステロール排泄量は胆 汁酸の変化に平行しないため胆汁は催石性となる。

一般に胆汁酸の胆汁内排泄量が減少すると胆汁流量 あ減少して胆汁は催石性となる。長時間の絶食または 夜間には，正常人でも胆汁酸プールの大部分が胆豪に 蓄積されて胆汁酸分泌は低下し, 肝胆汁のコレステロ 一ル飽和度は上昇する。したがって，胆汁のコレステ ロール過飽和状態は生理的にも出現する現象であり, 催石性胆汁は胆石形成の必要条件であっても十分条件 ではない。

\subsection{3 結石化機構}

コレステロールは, 過飽和度が高い領域 (Labile zone)ではコレステロールは速やかに析出して Homogenous nucleation が起てり, 過飽和度の低い領域 (Metastable zone) ではコレステロール結晶の析出 はゆっくりで，異質の小物質を核とする Heterogenous nucleation が起とる ${ }^{5,6)}$ という(図 4)。しかし, 三角 図の臨界ミセル曲線は, 総胆汁脂質濃度, 温度, 胆汁 酸の種類や塩類濃度などで影響を受けるので結石形成 の条件は単純なあのではない。

一般に, コ石症例の胆汁中にはコレステロール結晶 が常に証明されることから, 非胆石症例の単なるコレ ステロール過飽和胆汁よりは胆石形成と関係が深いと 考えられる。しかし，コレステロール過飽和の状態で あ結晶化しないあのがあることから, Antinucleation agents または Antigrowth agentsの存在の可能性も

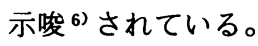

さて, 胆汁中に析出したコレステロール結晶は動物 実験によると, 胆汁中で凝集したり首状成長をしなが ら大きくなり板状の構築単位を形成して，てれが微小 結石・砂状の胆石へと成長し，コレステロール結晶は 中心より外に向かって放射状に配列して幾何学的選択 によって成長する ${ }^{7,8)}$ という。この点に関して, 次項 で教室の成績を少し述べることにする。

次に, 胆石成長の場としての胆囊の役割も重要であ る(図1)。例えば, コ石症例では手術で胆旁を摘出す ると胆石が再発することはないが, なんらかの理由で 胆囊を摘出せず胆石のみを摘出した場合には手術後胆 石が高頻度で再発する。

また, 胆震は胆汁酸の腸肝循環の機械的ポンプ役を 
行なっているが, 胆囊の機能不全ではこのポンプ作用 の障害から肝への胆汁酸還流量が減少して胆汁は催石 性が高まる。同時に胆囊は収縮不良のために胆汁うっ 滞が生じ, 胆汁は層を形成する。乙の胆囊胆汁の層形 成はコレステロールの結晶成長には好条件となる。

また, 胆石中にびまん性に分布するムコ物質（ムチ ン）の存在から, 胆囊粘膜内またはそれに近接した胆 汁中のムコ物質の存在も胆石形成に大きな役割を演じ ているあのと推測され, 胆囊胆汁が保有する Nucleation factor ${ }^{9)}$ が注目されている。

\subsection{4 コレステロール結晶の成長}

さて, Nucleationした微細なコレステロール結晶が 肉眼的サイズの胆石にまで育つ過程はほとんど解明さ れていないといってよい。著者らは結晶成長学の立場 からての過程を検討してきたので簡単に紹介する。

コ石で手術を受けた患者の胆囊胆汁を偏光顕微鏡で 観察すると, 大部分の症例で胆汁採取直後から多数の Cholesterol monohydrate crystal を認める。長 辺が $10 \sim 100 \mu \mathrm{m}$ 程度で極めて薄い平行四辺形の板状 結晶である。胆汁を放置しておくと，乙れらの微細な 単結晶はサイズが大きくなるとともにその数む増えて くる。すなわち，核生成および結晶成長という二つの 過程が同時に進行している。そてで，さらに分解能の 高い位相差顕微鏡を用いて結晶面を観察すると様々な Stepが認められる。一際目立つのは, 渦巻き状のStep であり, Screw dislocation に伴った Spiral step である(図 5 )。Facet が広く発達した結晶の形態から 考えても，乙れらが胆汁中で沿面成長 (Lateral growth) を行なっていることが推測されるわけである。 この明瞭なStepの Morphologyをとらえたのはわれ われが最初 ${ }^{10)}$ である。ヒト胆汁中のコレステロール単 結晶が沿面成長を行なっているととは明らかとなった が, 個々の単結晶がどのようにして球状の多結晶体の 胆石にまで育つのかは明らかではない。そてで結晶の 成長を経時的に“その場観察 (in situ observation)”

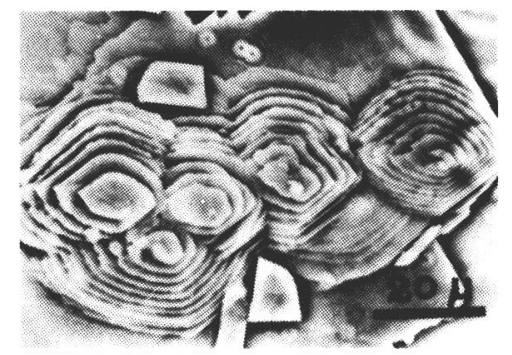

图 5 ヒト胆汁中のコレステロール単結晶 (多数のSpiral step あり, 位相差顕微鏡写真)

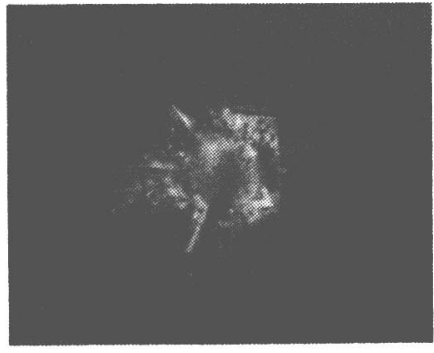

図 6 モデル胆汁中で成長した球晶 （偏光顕微鏡写真）

する必要がある。ヒ卜胆汁は組成が極めて複雑で, 個 々の症例に扣けるコレステロールの過飽和度む問題が あり，また胆汁色素の褐色色調は結晶の光学的観察を 妨げる可能性が大きいなどの理由から，われわれはモ デル胆汁を作製し, Cholesterol monohydrate cry stalの成長を経時的に“その場観察”するととにした。 モデル胆汁は $\mathrm{pH} 7.5$ のリン酸緩衝液にタウロケノデ オキシコール酸とレシチンをそれぞれ $100 \mathrm{mM}, 40 \mathrm{mM}$ の濃度になるよう溶解したミセル系にコレステロール を加えたものである。

Nucleation し成長してきたコレステロール結晶の 形態は, ヒ卜胆汁中の単結晶とよく似ており, 結晶表 面にはSpiral step が観察された。さらに，長時間に わたって結晶の育成を続けると, 多数の板状結晶が放 射状に集合して，全体として球形をなすようになった (図 6 )。乙のような球形の多結晶体を球晶と呼ぶが, この球晶の結晶構築はサイズは小さいものの純コレス テロール石(図 2) 亿類似している。なお, 板状結晶が 放射状に配列して球晶となるメカニズムはまだ明らか ではない。

\section{2 ビリルビンカルシウム石}

ビリルビンカルシウム石はかってわが国の代表的な 胆石であり，とくに東北地方に多いとされてきた。。゙ リルビンカルシウム石（以下ビ石）の主成分はビリル ビンカルシウムであるが，その他コレステロール，脂 肪酸カルシウム, 胆汁酸などもかなり含まれる。外観 は茶褐色から黒褐色を示し, 割面では年輪状の層状構 造を示すすの（図 7) とまったく無構造泥状塊のあのと がある。一般に, 軽くて脆い胆石で主に胆管系で形成 され，再発しやすい胆石である。ビ石の成因に関して は東北大学第一外科教室の成績を中心に述べることに する。

\section{2.1 誘 因}

わが国では, 第二次世界大戦前および戦後10年ぐら 


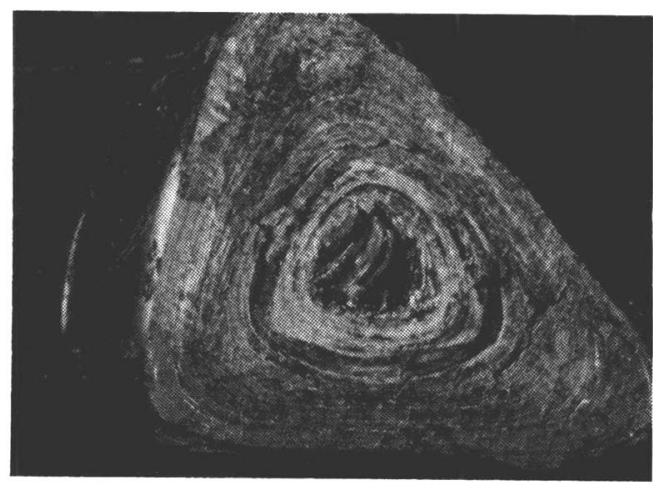

図7 ビリルビンカルシウム石(割面)

いまでは地域により多少の差はあってあ，一般的には 全胆石症手術例の 50〜 60\% はビ石であった。しかし， 近年ビ石は全胆石の 10 20\%を占めるのみとなり著 しく減少している。てのビ石の变遷は, ビ石の成因に 関して重要な示唆を与えるものである。

ビ石は, 細菌感染と密接な関係を有するてとが古く から指摘されていた。ビ石症例の胆汁中の細菌検出率 はコ石症例に比して極めて高く, 検出される主な菌種 は $70 \%$ が大腸菌で, 他は嫌気性菌など種々様々であ る。また, 回虫が胆道(図1)に迷入して胆汁の污染が 起こると, 胆石が形成される可能性がある。近年, 公 衆衛生の㣲底から回虫の寄生率は激減したが, 戦前あ るいは戦後まむない時期にビ石の頻度が高かったてと は, 回虫と極めて密接な関係を有していたてとを物語 るあのである。

ビ石生成には胆道系の胆汁うっ滞あ重要な因子であ る。回虫が胆道内に迷入すると,ファーター乳頭部 （図 1）に強い機械的刺激が加わり，急性または慢性の 乳頭炎が発生し胆汁うっ滞を惹起する。乳頭炎は, ビ 石形成の局所的誘因として重要な意味をむつあのであ る。ビ石の形成と食物の関係では, 日本人の従来の食 生活の組成内容(高炭水化物・低脂肪食) は, 胆汁組成 の検索からビ石の生成を促進させる可能性が強いこと が示唆されている。

\subsection{2 ビリルビンカルシウムの析出機構}

ビ石の主成分であるビリルビンカルシウム (Calcium bilirubinate)は, 遊離型ビリルビンのカルボキシル基 にカルシウムが結合したあのである。したがって, 胆 石中のビリルビンカルシウムは, 胆汁中の抱合型ビリ ルビンが加水分解されて遊離型ビリルビンを生成し, カルシウムと結合して水不溶性のビリルビンカルシウ ムになる必要がある。
胆汁中のビリルビンは， $96 \%$ 以上が 抱合型ビリル ビンであり，その約 $60 \%$ はビリルビングルクロナイ ド(Bilirubin glucuronide) で占められている。ての ビリルビングルクロナイドを加水分解する酵素に $\beta$ グルクロニダーゼ $(\beta$ - glucuronidase $: \beta-G)$ があ る。ビ石症例の胆汁では, $\mathrm{pH} 7.0$ 付近に $\beta-\mathrm{G}$ 活性 の極大が認められ, $こ の ~ \beta-G$ 活性は大腸菌由来の $\beta$ $-G$ である。事実, 健常人の胆汁に市販の細菌性 $\beta-$ $\mathrm{G}$ を添加するとビリルビンカルシウムの沈殿を認める。 最近は嫌気性菌の $\beta-\mathrm{G}$ あビリルビングルクロナイド の加水分解酵素として注目されている。

なお, 胆汁中ビリルビンは, 胆汁の $\mathrm{pH}$ をアルカリ 性にすると, 細菌の関与がなくとも遊離型ビリルビン が増加してビリルビンカルシウムを生成する可能性が ある。

さて, 胆汁中の大腸菌が $\beta-\mathrm{G}$ 活性を現わすか否か は, 感染細菌の量, および細菌の有する $\beta-\mathrm{G}$ 活性の 強弱が関係するが，むうひとつの因子として $\beta-\mathrm{G}$ 活 性阻害物質の存在がある。 $\beta-\mathrm{G}$ の特異的阻害物質に グルカロー1,4-ラクトン(Glucaro-1,4-lactone) がある。ビ石症例の胆汁中のグルカロ $-1,4$-ラクト ン(グルコ糖酸として測定する) 量は健常例胆汁の $1 / 5$ 量と低く，また，グルコ糖酸の量と $\beta-\mathrm{G}$ 活性阻害率 とは正の相関を示す。すなわち,グルコ糖酸（グルカ ロー 1, 4 -ラクトン) が多量に存在する症例では $\beta$ $\mathrm{G}$ 活性の阻害率が高く, 胆汁中のビリルビングルクロ ナイドは加水分解されにくいことになる。教室の動物 実験でも高炭水化物・低脂肪食で飼育したラットの胆 汁はグルコ糖酸量が低い。その他, $\beta-G$ 活性阻害物 質としては胆汁酸も無視できない。

以上の成績から，正常例では胆汁中のグルカロ - 1 , 4 -ラクトンの作用によりビリルビングルクロナイド は加水分解されないが, 病的状態では胆汁うっ滞に細 菌感染が起こり, 細菌性 $\beta-G$ 活性が増強して胆汁中

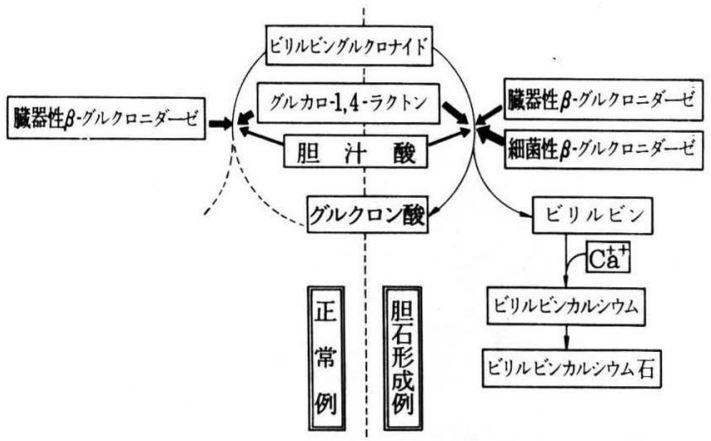

図 8 ビリルビンカルシウムの析出機構 
ビリルビングルクロナイドは加水分解されて遊離型ビ リルビンを生成し，カルシウムと結合してビリルビン カルシウムを形成するあのと考える(図 8)。

\subsection{3 凝集・結石化機構}

胆汁中に析出したビリルビンカルシウムの粒子が凝 集し結石化するためには，第一に電解質による静電気 的作用，第二には線状有機高分子電解質による粒子の 架橋作用 (Bridging action), 第三には運動エネルギ 一の付加が必要である(図 9)。人体内に最む普通にみ られる高分子物質としてはムコ物質 (ムチン)がある。 古くからムコ物質は胆石形成になんらかの役割を演じ ている可能性が推察されていた。事実, 酸性基を有す るムコ物質は胆石の全域にわたり網目状に分布し, 胆 石や胆汁の化学分析でこのムコ物質は主に硫酸化糖蛋 白(Sulphated glycoprotein) であることが証明され た。そして，乙の胆汁中の硫酸化糖蛋白は胆汁中に析 出した粒子を激しく凝集させることあ判明した。すな わち, 胆石生成には胆汁中の硫酸化糖蛋白が線状有機 高分子物質として，胆汁中に析出した結石成分を凝集 ・結石化するのに極めて重要な働きをしていることに なる。胆汁中に析出した粒子の凝集・結石化について は次項で少し詳細に述べることにする。

\subsection{4 惩濁粒子の凝集・結石化}

著者らは, 胆汁中に析出した水不溶性の胆石構成成 分がどのようにして凝集して結石化するかを検討し た。一般に，疎水性コロイドおよび懸濁液の安定性は Verwey - Overbeek の説から粒子間に作用する van der Waals attractive potential energy $\left(V_{A}\right)$ と Repulsive potential energy $\left(V_{R}\right)$ の両者 から決定 される Potential energy barrier $\left(V_{m}\right)$ によって支配 されるあので, $V_{m}$ が粒子の運動エネルギーより大で あれば粒子の凝集は妨げられ，逆に低ければ疑集が起

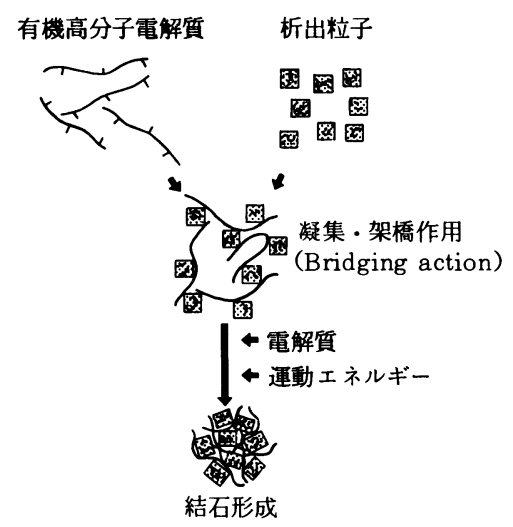

図 9 熙濁粒子の凝集・結石化機構
こると考えられている。乙の $V_{m}$ は固体表面の電位や イオン雾囲気の厚さなどの関係から決まるあのである。 そこで, この $V_{m}$ を低めるために 䊝濁液に適当な電解 質を加えると, イオン雾囲気の厚さの圧縮や，Zeta電位 ( $\zeta$ )の低下をきたし, 粒子間の反発力が減少し, $V_{A}$ の効果が優勢となり粒子は凝集を起てす。すなわ ち, 電気二重層の理論により特異吸着の存在しない場 合は Schultz-Hardy の法則にしたがって凝集するわ けである。著者らは, 均一なビリルビンカルシウムの 粒子を生体から大量に入手するてとができないので, 胆石に炭酸カルシウムを主成分とする白色, 無構造の あのがあることから, 市販の沈降性炭酸カルシウムの 馝濁液を用いて各種電解質による凝集を検討した。と くに，有機高分子電解質による疑集は市販のアルギン 酸ナトリウムのほか各種の凝集剤を用いたが, 炭酸力 ルシウム粒子はてれら電解質の低濃度の添加で激しく 凝集して, 熙濁液の上清は透明となり， 号を反転した。また，高濃度に添加すると逆に粒子は 分散し, 溶液は白濁した。

アルギン酸ナトリウムは線状有機高分子物質であり， 生体のムコ物質に類似する構造を有している陰性線状 高分子電解質である。したがって，陽荷電を有する炭 酸カルシウム粒子表面には容易に吸着し, 分子中のカ ルボキシル基において炭素カルシウム粒子と結合し, 架橋的 (Bridging action)に粒子を連結して巨視的な 凝集粒子になる。乙の際，さらに無機電解質を添加す ると,アルギン酸ナトリウムの線状構造は「糸まり状」 となり, 炭酸カルシウム粒子の表面荷電が中和され, $\zeta$ 一電位は低下して凝集が促進される。乙のように有 機高分子電解質による凝集機構は，有機高分子物質中 に含まれる官能基, すなわち硫酸基, カルボキシル基 やアミド基などを通じて水素結合, 化学結合または静 電気結合などによって粒子を架橋して凝集させるあの

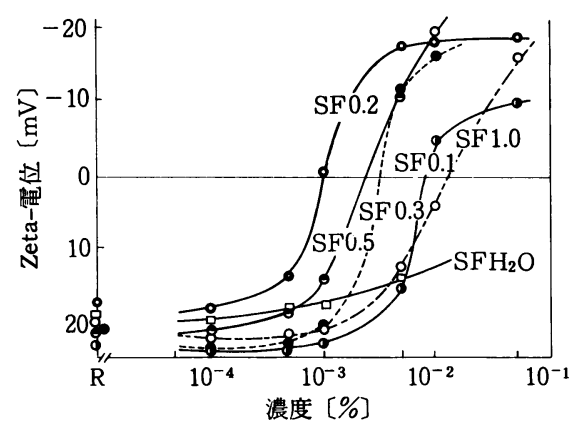

図 10 ビ石例 胆汁中么 (炭酸カルシウム緜濁夜の Zeta-電位) 
と考えられる。この場合，粒子の表面荷電と反対符号 の有機高分子電解質は粒子に対する吸着の容易さや粒 子表面荷電の中和などにより凝集にとって好条件を与 えている。

生体から抽出したムコ物質 (家鬼の腸粘膜粗物質, ヒト胃粘膜酸性画分）は低濃度で凝集が起こり， 電位の変化むアルギン酸ナトリウムと同一であった。 また，ビ石症例の胆汁から抽出したムコ物質の Frac-

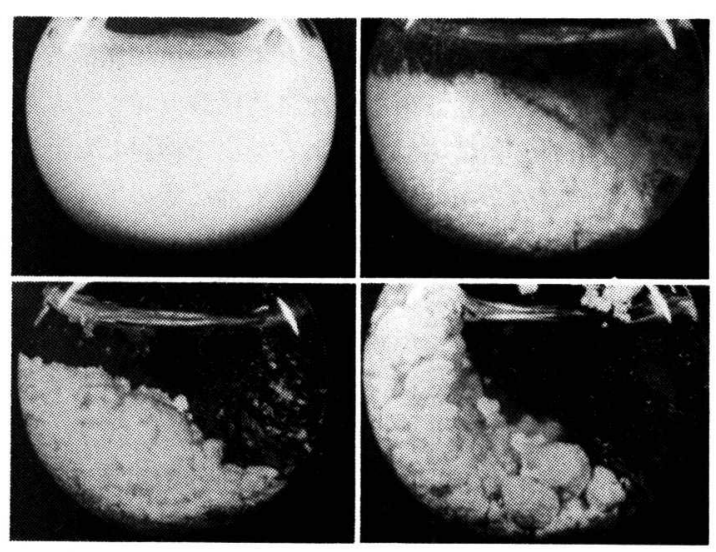

図 11 胆石様凝塊形成過程

（左上: 炭酸カルシウム䯚濁液, 右上 : 凝集剤を添加して回転エネルギ 一を負荷, 左下：小疑塊生成, 右下 : 胆石様凝塊）

\section{引用 文 献}

1）鈴木範美，佐藤寿雄：胆と膵， 7, 1476 (1986)

2) Small, D. M. : Adv. Intern. Med., 16, 243 (1970)

3) Admirand, W. H. and D. M. Small : J. Clin. Invest., 47, 1043 (1963)

4) Holzbach, R. T. and C.Y.C. Pak : Am. J. Med., 56, 141 (1974)

5 ) Carey, M. C., and D. M. Small : J. Clin. Invest., 61, 998 (1978)

6 ) Small, D. M. : N. Engl. Med., 302, 1305 (1980)

7 ) Osuga, T., O. W. Portman, et al : Lab. Invest., 30, 486 (1974)

8 ) Osuga, T., K. Mitamura, et al. : Lab. Invest., 31, 696 (1974) tion 2 は凝集効果が強力であり, Fraction 2 をさら に分画溶出させた Subfraction $0.2 \mathrm{M} \mathrm{NaCl}$ は低濃度 の添加で激しく凝集して $\zeta$ 一電位は符号を逆転した (図 10)。その化学分析では, Hexose, Hexosamine, L - fucoseのほか硫酸が少量含まれる硫酸化糖蛋白で あった。

著者らは, さらに胆石様凝塊をつくるために最適の 凝集条件の下で炭酸カルシウム懸濁液に回転のエネル ギーを加えたところ，無構造の胆石様凝塊を作成する ことができた(図11)。in vitroで作成した炭酸カルシ ウムの胆石様凝塊はヒト炭酸カルシウム石と組織化学 的にきわめて類似していた。

おわりに

胆石の成因に関して，コレステロール胆石とビリル ビンカルシウム石についてその概要を解説した。また, コ石についてはコレステロールの結晶成長について, ビ石に関しては炭酸カルシウム懸濁液の凝集分散につ いて教室の成績を述べ，それぞれの胆石の結石化機構 について推察した。

胆石の主構成成分の胆汁中への析出機構はある程度 解明されてきているが, 胆汁中に析出した結晶がいか に成長し結石化するか，また懸濁粒子がいかに凝集し， 結石化するかについての研究はてれからの課題である。

9) Burnstein,M. J., R. G. Ilson, et al. : Gastroenterology, 85, 801 (1983)

10）田中純一, 伊勢秀雄ほか: 日消誌, 83, 1816 (1986)

11）佐藤寿雄, 鈴木範美: 最新医学, 30,936 (1975)

12) Maki, T., T. Matsushiro, et al. : "Intrahepatic calculi” p. 81, Alan R. Liss Inc.(1984)

13) Maki, T. and N. Suzuki : Tohoku J. Exp. Med., 84, 259 (1964)

14) Maki, T. and N. Suzuki : Tohoku J. Exp. Med., 88, 181 (1966)

15) Nagashima, H., N. Suzuki, et al. : Tohoku J. Exp. Med., 113, 225 (1974) 